\title{
Humanity Beyond Borders
}

Boris Schmidt Goldstein

Within the Middle East, many nations are war-ravaged, thus limiting available healthcare. Not only has the need for medical treatment surged with the outbreak of COVID-19, but many medical centers throughout the Middle East are neither equipped with sufficient technology nor comprised of well-trained personnel in order to assist with life-threatening operations and treatments. However, there is one anomaly in the war-torn region- Israel. Since the nation's establishment in 1948, the highly-acclaimed Sheba Medical Center has played a large role in facilitating healthcare. It began as the first military hospital in order to treat casualties from the 1948 Arab-Israeli War, which was prompted by the Israeli Declaration of Independence and the resulting outrage from its Arab neighbors. The war lasted for nine months. After 1953, the military hospital was converted to a civilian hospital. Since then, Sheba Medical Center has had prominent influence within the Middle East and facilitates medical research in many areas, greatly shaping modern medicine. Newsweek ranks the medical center as the ninth-best hospital in the world, alongside other notable hospitals such as Mayo Clinic and Toronto General Hospital (1). Sheba has recorded 200,000 ER visits and over 2,000,000 patients treated annually both domestically and internationally (2). Many of their emergency visits are provided to international patients, primarily within the Middle East.

\section{“However, Operation Good Neighbor's running of aid through southern Syria came to a halt after Syrian President Bashar al-Assad's forces defeated the Free Syrian Army in the 2018 Southern Syria offensive (3)."}

A large percentage of these patients are children from the Palestinian Authority, which lacks sufficient neonatal care units. The Palestinian Authority processes and transfers thousands of patients in order to obtain urgent hospitalization, primarily for critical operations. Israel, despite rivalries, continues to provide aid to its Arab neighbors enabling medical access for civilians for humanitarian causes. A notable example that exemplified Israel's international assistance to those deprived of proper healthcare was Operation Good Neighbor, which began administering medical aid through the Israeli Defense Forces to those affected by the Syrian Civil War. Over 110 operations were performed on patients brought to Israel through the Golan Heights, where northern Israel borders Syria. Many of these operations provided aid to children and admitted them to hospitals within the region. However, Operation Good Neighbor's running of aid through southern Syria came to a halt after Syrian President Bashar al-Assad's forces defeated the Free Syrian Army in the 2018 Southern Syria offensive (3).

Within just the past months, two emergent neonatal intensive care cases from the neighboring region outside of Israel required transfer to Sheba Medical Center. The first involved the child of a Syrian refugee currently living in Cyprus. The 10-day-old baby was flown into Israel through special coordination between the Cypriot and Israeli government so that the infant could undergo the first of three surgeries for his rare congenital heart defect, hypoplastic left heart syndrome (4). HLHS disrupts normal blood flow and greatly impacts the left side of the heart, preventnig it from properly pumping oxygen-rich blood to the rest of the body. Without treatment, it is fatal. HLHS is considered a critical CHD as it requires the affected infant to undergo the initial operation promptly after birth (5). The baby successfully underwent the first of the three scheduled surgeries, the Norwood procedure. The Norwood procedure creates an artificial aorta connected to the right ventricle of the heart and creates a conduit to supply the pulmonary arteries with sufficient blood flow. This surgery is the most challenging of the three procedures, and both oxygen-rich and oxygen-poor blood still mix in the heart following the operation. After the infant's recovery, he will return to Cyprus and be expected to return in 6 months to take the next step in the process with the Bi-directional Glenn Shunt procedure, which will lower the workload of the right ventricle by enabling the returning blood flow to redirect to the lungs. The infant will then return back to Sheba Medical Center 18 months after the second operation to finalize the repair with the Fontan procedure, which will also correct the mixing of oxygen-rich and oxygen-poor blood. This is the first emergency surgery since the initial outbreak of coronavirus. Similar cases involving HLHS were transferred urgently to Israel before the pandemic from other countries within the region where relations are not normalized with Israel, such as Syria and Iraq.

"Palestinian Authority President Mahmoud Abbas' recently decided to halt any mutual agreements with Israel and to withdraw from any cooperation between the two governments due to Israeli Prime Minister Benjamin Netanyahu's decision to apply Israeli sovereignty over regions of the West Bank."

However, while the region depends on Israel for its healthcare, new issues are evident. Palestinian Authority President Mahmoud Abbas' recently decided to halt any mutual agreements with Israel and to withdraw from any cooperation between the two governments due to Israeli Prime Minister Benjamin Netanyahu's decision to apply Israeli sovereignty over regions of the West Bank. This area comprises most of the Area $\mathrm{C}$ set by the Oslo Accords, where Israel holds military and civil control (6). This geopolitical obstacle will most likely hinder the delivery of Israel's healthcare, 
especially to the children of Gaza.

In the second instance of a neonatal emergency within the region, a 8-month-old's planned heart surgery for his life-threatening cardiac condition was delayed due to this halt in coordination from the Palestinian Authority. The procedure was promptly rescheduled through activism by humanitarian groups in the region, but the baby died three days before the rescheduled date (7). This infant had already received treatment from Sheba Medical Center at 1-month and was denied transfer due to the strained political relations between the two governments. If this issue remains prominent, many Palestinians will be affected as Palestinian hospitals are not able to facilitate aid because of insufficient resources, limited technology, and lack of specialized medical personnel.

Annually, there are thousands of permits given to Palestinian infants in order to undergo treatment at Israeli neonatal care units. However, with the straining of relations recently, an entire generation of infants may be deprived of proper healthcare.

\section{"Annually, there are thousands of permits given to Palestinian infants in order to undergo treatment at Israeli neonatal care units. However, with the straining of relations recently, an entire generation of infants may be deprived of proper healthcare."}

\section{References:}

1 .https://www.newsweek.com/2020/03/06/top-10-hospitalsworld-1489794.html

2. https://www.shebaonline.org/about-us/

3. https://www.ynet.co.il/articles/0,7340,L-5349571,00.htm/

4. https://www.timesofisrael.com/doctors-optimistic-as-syrianbaby-completes-1st-of-3-heart-surgeries-in-israel/

5. https://www.cdc.gov/ncbddd/heartdefects/hlhs. htm/\#: :text=Hypoplastic\%20left\%20heart\%20syndrome $\% 20$ (HLHS, Congenital\%20means\%20present $\% 20$ at\%20birth.

6. https://www.ochaopt.org/location/area-c

7. https://www.ynetnews.com/magazine/article/SJxTVWJAL
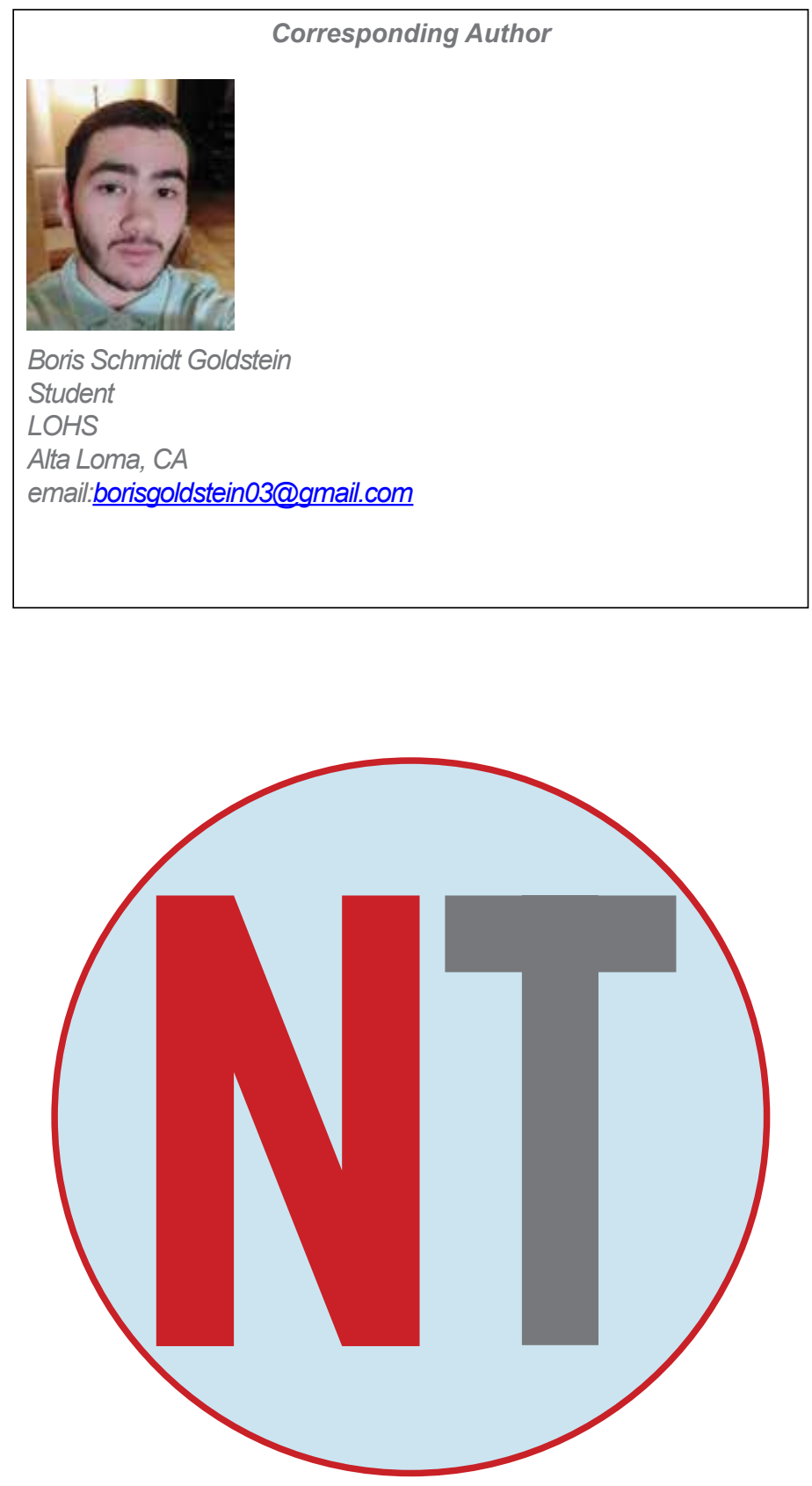

The author has no conflicts to disclose

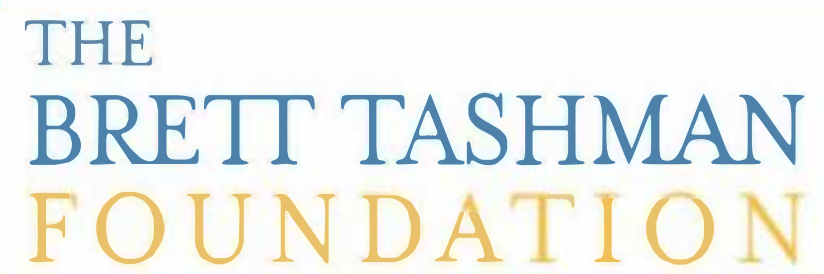

The Brett Tashman Foundation is a 501()(3) public charity. The mission of the Foundation is to find a cure for Desmoplastic Small Cell Round Tumors (DSRCT). DSRCT is an aggressive pediatric cancer for which there is no cure and no standard treatment. 100 percent of your gift will be used for research. There is no paid staff. To make your gift or for more information, go to "TheBrettTashmanFoundation.org" or phone (909) 981-1530. 